\title{
Effect of meat and bone meal (MBM) and Bacillus subtilis on the content of nitrogen and phosphorus in soil and white mustard biomass
}

\author{
Anna Nogalska, Małgorzata Skwierawska and Aleksandra Załuszniewska \\ Department of Agricultural Chemistry and Environmental Protection, University of Warmia and Mazury in Olsztyn, \\ 10-719 Olsztyn, Poland \\ e-mail: anna.nogalska@uwm.edu.pl
}

\begin{abstract}
The aim of this pot experiment was to determine the effect of increasing rates of meat and bone meal (MBM), applied alone or in combination with a microbial preparation containing Bacillus subtilis (FITOdoctor), on the growth of Sinapis alba L.. Dry matter (DM) yield, the nitrogen $(\mathrm{N})$ and phosphorus $(\mathrm{P})$ content of white mustard were determined, together with the mineral $\mathrm{N}\left(\mathrm{N}_{\min }\right)$ and available $\mathrm{P}$ content of soil. The application of FITOdoctor to the soil improved white mustard yield only during the second growing season. Second-harvest white mustard biomass had a significantly lower content of $\mathrm{N}$ and $\mathrm{P}$ than first-harvest biomass. The highest MBM rate significantly increased the $\mathrm{N}_{\min }$ content of soil. Nitrogen uptake by plants and $\mathrm{N}$ concentration in biomass were highest in the treatments with the highest mineral $\mathrm{N}$ content of soil. Similar relationships were observed for $\mathrm{P}$ whose uptake by plants was also affected by $B$. subtilis in two treatments (NPK, $0.8 \% \mathrm{MBM}$ ). MBM is a valuable $\mathrm{N}$ and $\mathrm{P}$ fertilizer, whereas $B$. subtilis has varied effects.
\end{abstract}

Key words: Sinapis alba L., animal meal, microorganisms, soil, nutrients, uptake

\section{Introduction}

Excessive use of chemicals in agriculture, intensive soil tillage and inadequate crop rotation have led to soil fertility decline. Recent years have witnessed a growing interest in eco-friendly soil amendments and crop protection methods. White mustard (Sinapis alba L.) is an oilseed crop grown for its seeds that are used as a spice. The species is also grown as fodder, green manure and mulch. When used as green manure and mulch, the amount of organic matter and nutrients supplied by white mustard biomass to the soil is comparable with that found in the recommended rates of manure (Harasimowicz-Hermann and Hermann 2006). White mustard also exerts phytosanitary effects and prevents soil erosion (Szymczak-Nowak and Nowakowski 2000). Meat and bone meal (MBM) can be an alternative to mineral nitrogen-phosphorus (NP) fertilizers on account of its high content of $\mathrm{N}$ (approx. $80 \mathrm{~g} \mathrm{~kg}^{-1} \mathrm{DM}$ ), $\mathrm{P}$ (approx. $50 \mathrm{~g} \mathrm{~kg}^{-1} \mathrm{DM}$ ) and Ca (approx. $100 \mathrm{~g} \mathrm{~kg}^{-1} \mathrm{DM}$ ) as well as micronutrients and organic matter (approx. $700 \mathrm{~g} \mathrm{~kg}^{-1} \mathrm{DM}$ ) (Jeng et al. 2006). MBM contributes to soil fertility, higher yields and better quality of agricultural products (Jeng et al. 2004, Chaves et al. 2005, Jeng et al. 2006, Chen et al. 2011, Brod et al. 2012, Nogalska and Zalewska 2013, Nogalska 2016, Nogalska et al. 2017).

The $20^{\text {th }}$ century has seen rapid advances in agricultural biotechnology, including the use of beneficial microorganisms in agriculture. Bacillus subtilis, which belongs to plant growth-promoting rhizobacteria (PGPRs), is widespread in the natural environment. This biologically active bacterial species can be a viable alternative to fungicides and nematicides (Cazorla et al. 2007, Rao et al. 2017). Bacteria of the genus Bacillus have been widely used for the production of enzymes, antibiotics, bioinsecticides and other metabolites. They are characterized by rapid growth and known to secrete numerous proteins outside of the cell. Bacillus subtilis promotes plant growth due to its ability to synthesize growth regulators (gibberellins, auxin and cytokinins), solubilize P and produce siderophores that chelate ferric iron. Bacillus species can increase $\mathrm{P}$ availability to plants by mobilizing poorly available forms of P in soil, such as calcium phosphates and organic compounds (Patel et al. 2010, Wang et al. 2011, Zuo and Zhang 2011, García-López et al. 2015). They can also indirectly mitigate or prevent diseases caused by pathogens, including nematodes, in numerous host plant species (Cawoy et al. 2011). These microorganisms, referred to as biofertilizers, offer an alternative to mineral fertilizers and constitute green biotechnology tools (Al-Taweil et al. 2009). Bacillus subtilis have been classified as GRAS (generally recognized as safe) by the US Food and Drug Administration. In Poland, bacteria of the genus Bacillus (B. subtilis and B. thuringiensis) have been classified into the second risk group according to the Regulation of the Minister of Health of 22 April 2005. Recent research has shown that $B$. subtilis has no specialized mechanisms by which pathogens colonize human and/or animal hosts (Kozajda and Szadkowska-Stańczyk 2012). Nevertheless, the use of microbial preparations as substitutes for chemical agents in agriculture and horticulture remains controversial. 
The objective of this study was to determine the effect of increasing rates of MBM, applied alone or in combination with a microbial preparation (FITOdoctor) containing B. subtilis, on the dry matter (DM) yield, N and P content of and uptake by white mustard (Sinapis alba L.). The concentrations of mineral $N\left(N_{\text {min }}\right)$ and available $P$ in soil were also analyzed.

\section{Materials and methods \\ Experimental plot}

A greenhouse experiment was conducted in 2013 at the University of Warmia and Mazury in Olsztyn (Poland), in a completely randomized design with four replications. Modified Kick-Brauckmann pots (volume - 9 I, diameter $23 \mathrm{~cm}$ ) were filled with $10 \mathrm{~kg}$ of soil with the following chemical properties: $\mathrm{pH}$ in $1 \mathrm{~mol} \mathrm{KCl}$ solution $=5.33$, and moderate levels of available $\mathrm{P}, \mathrm{K}$ and $\mathrm{Mg}$ (Table 1 ). Soil moisture content in pots was maintained at $60 \%$ of the maximum water capacity. The nutrient status of soil was determined based on the Polish classification system. The soil material was collected from the surface horizon of Haplic Cambisol (FAO 2014) which had the texture of loamy sand. The tested crop species was white mustard (Sinapis alba L.) grown as green fodder, sown twice during the year into the same soil, at 10 seeds per pot, at a depth of $2 \mathrm{~cm}$. Before the second sowing, the soil was loosened (not mixed), and the tap roots remaining after the first harvest were removed. White mustard was harvested after 5 weeks, in the full flowering stage.

MBM was applied as a slow-release nitrogen-phosphorus fertilizer, at a single rate, before the first sowing of white mustard. Increasing rates of MBM were mixed with soil according to the experimental design involving 10 treatments. MBM was purchased from the authorized Animal By-Products Disposal Plant Saria (Długi Borek, Poland). Increasing rates of $\mathrm{MBM}$ were mixed with soil according to the experimental design involving the following 10 treatments: 1) "O" - no fertilizer; 2) "0" + Bs - no fertilizer, B. subtilis; 3) NPK - mineral fertilizer, no B. subtilis; 4) NPK + Bs - mineral fertilizer and $B$. subtilis; 5) $0.2 \% \mathrm{MBM}-0.2 \% \mathrm{MBM}$ per pot filled with $10 \mathrm{~kg}$ of soil, no $B$. subtilis; 6 . $0.2 \% \mathrm{MBM}+\mathrm{Bs}-0.2 \% \mathrm{MBM}$ and B. subtilis; 7) $0.4 \% \mathrm{MBM}-0.4 \% \mathrm{MBM}$, no B. subtilis; 8 ) $0.4 \% \mathrm{MBM}+\mathrm{Bs}-0.4 \%$ MBM and $B$. subtilis; 9) $0.8 \% \mathrm{MBM}-0.8 \% \mathrm{MBM}$, no $B$. subtilis; 10$) 0.8 \% \mathrm{MBM}+\mathrm{Bs}-0.8 \% \mathrm{MBM}$ and $B$. subtilis.

The chemical properties of MBM are shown in Table 1. MBM rates of $0.2,0.4$ and $0.8 \%$ weight basis supplied 1.5 , 3.0 and $6.0 \mathrm{~g} \mathrm{~N} \mathrm{pot}^{-1}$, and 1.0, 2.0 and $4.0 \mathrm{~g} \mathrm{P} \mathrm{pot}^{-1}$, respectively. Since MBM has relatively low K content, $\mathrm{K}$ was supplied by mineral fertilizers, at the rate corresponding to potassium fertilizer levels in the control (NPK) treatment.

\begin{tabular}{|c|c|c|c|}
\hline Parameter: Soil / MBM & Unit: Soil ; MBM & Soil & MBM \\
\hline Dry matter (DM) & $\mathrm{g} \mathrm{kg}^{-1}$ & 960 & 970 \\
\hline $\mathrm{pH}-1 \mathrm{M} \mathrm{KCl} / \mathrm{H}_{2} \mathrm{O}$ & - & 5.33 & 5.80 \\
\hline Total N & $\mathrm{mg} / \mathrm{kg} ; \mathrm{g} / \mathrm{kg}$ & 1.10 & 75.2 \\
\hline Available P & $\mathrm{mg} / \mathrm{kg} ; \mathrm{g} / \mathrm{kg}$ & 62.1 & 47.5 \\
\hline Available K & $\mathrm{mg} / \mathrm{kg} ; \mathrm{g} / \mathrm{kg}$ & 111.8 & 3.42 \\
\hline Available Mg & $\mathrm{mg} / \mathrm{kg} ; \mathrm{g} / \mathrm{kg}$ & 45.0 & 2.0 \\
\hline Available Ca & $\mathrm{mg} / \mathrm{kg} ; \mathrm{g} / \mathrm{kg}$ & 422 & 100.3 \\
\hline Organic matter & $\mathrm{g} \mathrm{kg}^{-1} \mathrm{DM}$ & 8.11 & 714 \\
\hline
\end{tabular}

In the control treatment, NPK fertilizer was applied before the first and second sowing of white mustard (per pot): $1.5 \mathrm{~g} \mathrm{~N}$ applied as $\mathrm{CO}\left(\mathrm{NH}_{2}\right)_{2}$ (three equal rates of $0.5 \mathrm{~g}$ each; one pre-sowing application followed by two top dressing applications), $0.5 \mathrm{~g} \mathrm{P}$ as $\mathrm{KH}_{2} \mathrm{PO}_{4}$ (pre-sowing application) and $1.0 \mathrm{~g} \mathrm{~K}$ as $\mathrm{KH}_{2} \mathrm{PO}_{4}$ and $\mathrm{KCl}$ (pre-sowing application). During two mustard growing seasons, $3.0 \mathrm{~g} \mathrm{~N}, 1.0 \mathrm{~g} \mathrm{P}$ and $2.0 \mathrm{~g} \mathrm{~K}$ per pot $^{-1}$ were applied in this treatment. Unfertilized soil was also used as a control treatment.

A slow-release microbial preparation known under the brand name of FITOdoctor (AGRARIUS Ltd.) was tested in the study. FITOdoctor contains $B$. subtilis at $5 \times 10^{9} \mathrm{CFU}$ (colony forming units) per gram of the preparation. The preparation was applied to the soil in liquid form (according to the manufacturer's recommendations), at a single rate of $1 \mathrm{~g}$ per $10 \mathrm{~kg}$ of soil in a pot $(250 \mathrm{ml}$ of solution per pot), before the first sowing of white mustard. All treatments were established on the day of mustard sowing. 


\section{Soil and plant analyses}

Before the establishment of the experiment, soil was analyzed as follows: available P and available $\mathrm{K}-$ by the Egner-Riehm DL method (soil: solution extraction ratio 1:50 m/v), and available $\mathrm{Mg}$ - by the Schachtschabel method (soil: solution extraction ratio $1: 10 \mathrm{~m} / \mathrm{v}$ ).

Soil samples were collected from pots after the second harvest of white mustard. The soil samples were analyzed as follows: $\mathrm{pH}$ in $1 \mathrm{M} \mathrm{KCl}$ (soil: solution extraction ratio 1:2.5 v/v) by the potentiometric method, content of ammonium $\mathrm{N}$ and nitrate $\mathrm{N}$ in fresh samples after extraction with $0.06 \mathrm{M} \mathrm{K}_{2} \mathrm{SO}_{4}$ (soil: solution extraction ratio 1:5 $\mathrm{m} / \mathrm{v}$ ) -colorimetrically $\left(\mathrm{NH}_{4}^{+}-\mathrm{N}\right.$ with Nessler's reagent, $\mathrm{NO}_{3}^{-}-\mathrm{N}$ with phenoldisulfonic acid, available $\mathrm{P}-$ by the Egner-Riehm DL method (soil: solution extraction ratio 1:50 m/v) (Panak 1997).

Dried, weighted and ground plant samples were wet mineralized in concentrated sulfuric acid (VI) with hydrogen peroxide $\left(\mathrm{H}_{2} \mathrm{O}_{2}\right)$ as the oxidizing agent. Mineralized plant samples were assayed for the content of total $\mathrm{N}$ (with the sodium hypochlorite reagent) and total P by the vanadium-molybdenum method (Panak 1997). Nitrogen and phosphorus uptake were calculated based on the biomass produced and the content of a given nutrient in biomass.

\section{Statistical analysis}

The results were processed statistically by analysis of variance (ANOVA) in the STATISTICA 10 program (StatSoft 2010). The DM yield of white mustard and the results of chemical analyses were processed statistically by twoway ANOVA, with two experimental factors: factor 1 - increasing rates of MBM applied alone or in combination with the FITOdoctor microbial preparation, factor 2 - harvest date (first and second harvest). Soil test results were analyzed statistically by one-way ANOVA. The significance of differences between means was determined by Duncan's test at $p<0.01$.

\section{Results and discussion Plant yield}

Increasing rates of $\operatorname{MBM}(0.2,0.4$ and $0.8 \%$ per pot) had a significant effect on white mustard yield relative to the control (NPK) treatment (Table 2 ). MBM applied at the highest rate $(0.8 \%$ ) significantly (by $21 \%$ on average) increased the aboveground DM yield of white mustard in comparison with the NPK treatment. In the treatment with the highest MBM rate, both the first- and second-harvest biomass yields were high (32.66 and $31.85 \mathrm{~g} \mathrm{pot}^{-1}$ DM, respectively).

Table 2. Yield ( $\left.\mathrm{g} \mathrm{pot}^{-1} \mathrm{DM}\right)$ and nitrogen and phosphorus content ( $\left.\mathrm{g} \mathrm{kg}^{-1} \mathrm{DM}\right)$ of white mustard

\begin{tabular}{|c|c|c|c|c|c|c|c|c|c|}
\hline \multirow[t]{2}{*}{ Treatment } & \multicolumn{3}{|c|}{ Yield } & \multicolumn{3}{|c|}{$\mathrm{N}$} & \multicolumn{3}{|c|}{$P$} \\
\hline & I & II & $\begin{array}{c}\text { mean for } \\
\text { rate }\end{array}$ & I & II & $\begin{array}{c}\text { mean for } \\
\text { rate }\end{array}$ & I & II & $\begin{array}{c}\text { mean for } \\
\text { rate }\end{array}$ \\
\hline 0 (no fertilizer) & 14.36 & 5.25 & $9.81^{\mathrm{a}}$ & 11.93 & 12.57 & $12.25^{a}$ & 1.73 & 1.42 & $1.57^{\mathrm{a}}$ \\
\hline $0+B s$ & 17.48 & 5.69 & $11.58^{\mathrm{a}}$ & 11.94 & 15.19 & $13.56^{a}$ & 1.83 & 1.51 & $1.67^{\mathrm{ad}}$ \\
\hline NPK & 27.85 & 25.53 & $26.69^{c}$ & 39.91 & 29.17 & $34.54^{d}$ & 2.15 & 1.93 & $2.04^{\mathrm{ce}}$ \\
\hline $\mathrm{NPK}+\mathrm{Bs}$ & 27.68 & 32.31 & $29.99^{\text {de }}$ & 38.15 & 32.50 & $35.32^{d}$ & 2.07 & 2.08 & $2.07^{c}$ \\
\hline $0.2 \% \mathrm{MBM}$ & 26.69 & 14.18 & $20.43^{b}$ & 24.86 & 12.83 & $18.84^{b}$ & 1.75 & 1.50 & $1.62^{\mathrm{a}}$ \\
\hline $0.2 \% \mathrm{MBM}+\mathrm{Bs}$ & 24.79 & 17.14 & $20.96^{b}$ & 29.48 & 13.25 & $21.36^{\mathrm{b}}$ & 1.95 & 1.71 & $1.83^{\mathrm{bd}}$ \\
\hline $0.4 \% \mathrm{MBM}$ & 29.28 & 25.10 & $27.19^{c d}$ & 40.95 & 16.68 & $28.81^{c}$ & 1.94 & 1.78 & $1.86^{\text {be }}$ \\
\hline $0.4 \% \mathrm{MBM}+\mathrm{Bs}$ & 28.48 & 25.98 & $27.23^{\mathrm{cd}}$ & 50.76 & 17.67 & $34.21^{d}$ & 1.94 & 1.77 & $1.85^{\mathrm{bd}}$ \\
\hline $0.8 \% \mathrm{MBM}$ & 32.66 & 31.85 & $32.25^{\mathrm{ef}}$ & 51.69 & 35.30 & $43.49^{\mathrm{e}}$ & 2.03 & 2.00 & $2.01^{\mathrm{ce}}$ \\
\hline $0.8 \% \mathrm{MBM}+\mathrm{Bs}$ & 36.45 & 33.03 & $34.74^{f}$ & 52.34 & 35.39 & $43.86^{e}$ & 2.04 & 2.06 & $2.05^{c}$ \\
\hline Mean for harvest & $26.57^{b}$ & $21.61^{a}$ & 24.09 & $35.20^{\mathrm{b}}$ & $22.05^{\mathrm{a}}$ & 28.63 & $1.94^{b}$ & $1.78^{\mathrm{a}}$ & 1.86 \\
\hline$d \times h$ & \multicolumn{2}{|c|}{$\mathrm{s}$} & - & \multicolumn{2}{|c|}{$\mathrm{s}$} & - & \multicolumn{2}{|c|}{$\mathrm{s}$} & - \\
\hline
\end{tabular}

0+Bs = Bacillus subtilis without fertilizers; NPK = mineral fertilization; $\mathrm{MBM}=$ meat and bone meal applied in increasing rates alone or in combination with Bacillus subtilis; I and II = first and second harvest of white mustard; $(\mathrm{d} \times \mathrm{h})=$ interaction between rate and harvest; $\mathrm{s}=$ significant difference at $p<0.01$. Values within a row (mean for harvest) marked with the same letter are not significantly different at $p<$ 0.01 . Values within a column (mean for rate) marked with the same letter are not significantly different at $p<0.01$.

The amount of $\mathrm{N}$ supplied per pot $(6.0 \mathrm{~g})$ by the highest MBM rate was twofold higher than in the control treatment during two mustard growing seasons. White mustard yields in the treatment with the medium MBM rate $(0.4 \%)$ and in the control treatment were comparable, and the amount of supplemental $\mathrm{N}$ was identical in both treatments $\left(3.0 \mathrm{~g} \mathrm{pot}^{-1}\right)$. A beneficial influence of $\mathrm{MBM}$ on crop yields has been reported by many authors (Jeng et al. 2004, 2006, Chaves et al. 2005, Ylivainio et al. 2008, Chen et al. 2011, Nogalska 2016). In the present study, 
MBM was incorporated into the soil at a single rate before sowing, whereas mineral fertilizer $\left(\mathrm{CO}\left[\mathrm{NH}_{2}\right]_{2}\right)-46 \% \mathrm{~N}$ was applied at $1.5 \mathrm{~g} \mathrm{~N} \mathrm{pot}^{-1}$ per growing season at three equal rates of $0.5 \mathrm{~g}$ each. The lowest rate of MBM $(0.2 \%)$, which supplied half the amount of $\mathrm{N}(1.5 \mathrm{~g} \mathrm{~N}$ per pot) relative to the NPK fertilizer, significantly reduced white mustard yield (by around $23 \%$ on average). The decrease in average yield in this treatment resulted from nearly two-fold lower biomass produced during the second growing season by white mustard grown in the same soil. It appears that the lowest rate of MBM was insufficient to meet the $\mathrm{N}$ requirements of white mustard in the second growing season. Similar results were reported for maize (Nogalska et al. 2013).

The average DM yield of white mustard was $19 \%$ lower during the second harvest relative to the first harvest, and the noted difference was statistically significant (Table 2). In the second growing season, white mustard yields were approximately three-fold lower in unfertilized treatments and nearly two-fold lower in the treatment with the lowest MBM rate.

The FITOdoctor microbial preparation, which contains B. subtilis cells, contributed to a significant (over $12 \%$ ) increase in the average DM yield of white mustard only in the NPK treatment (Table 2). The yield of second-harvest white mustard was $27 \%$ higher in the NPK $+B$. subtilis treatment than in the NPK treatment without the microbial preparation. A yield-increasing effect of MBM combined with $B$. subtilis was noted only during the second growing season. The only exception was the treatment with the highest MBM rate $(0.8 \%)$ with $B$. subtilis where white mustard yield increased by approximately $12 \%$ already during the first growing season. It should be stressed that the microbial preparation was applied at a single rate before the first sowing of white mustard, which could indicate that its effect was spread over time. Naher et al. (2016) demonstrated that bacteria of the genus Bacillus applied with organic fertilizer significantly increased rice yields. The application of organic fertilizer with $B$. subtilis increased the uptake of both macro- and micronutrients by plants.

The total aboveground yield (first and second harvest) of white mustard per pot ranged from $19.61 \mathrm{~g} D \mathrm{D}$ in the unfertilized treatment to $69.48 \mathrm{~g}$ DM in the treatment with the highest MBM rate and FITOdoctor (Fig. 1). B. subtilis contributed to an increase (from 1.5 to 18\%) in the total DM yield of white mustard in all treatments, in comparison with the treatments where the microbial preparation was not applied. A beneficial influence of Bacillus sp. on crop yields, which was also observed by Qiao et al. (2017) and Othman and Panhmar (2014), could result from the adsorption of siderophores to iron oxide surfaces, which increased available P uptake by plants. Phytohormones (such as gibberellin) released by $B$. subtilis could also promote root growth, thus increasing nutrient uptake by plants. Due to the production of siderophores, PGPRs can regulate iron cycling in plants and soil.

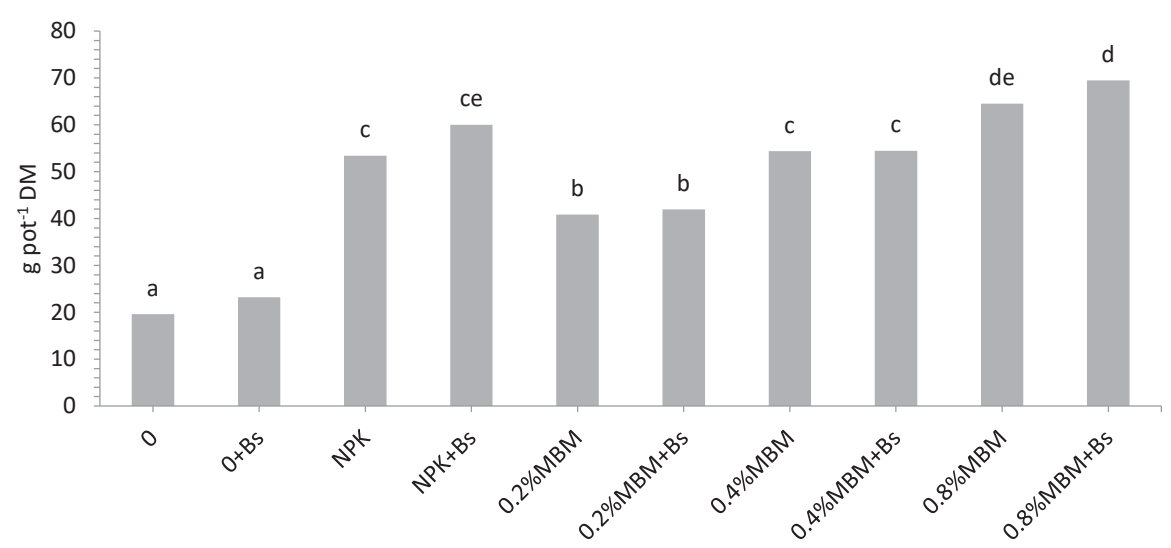

Fig. 1. Total yield (sum of the first and second harvest) of white mustard $(0+B s=$ Bacillus subtilis without fertilizers; NPK = mineral fertilization; $\mathrm{MBM}=$ meat and bone meal applied in increasing rates alone or in combination with Bacillus subtilis. Values within above the column marked with the same letter are not significantly different at $p<0.01$.)

\section{Nitrogen and phosphorus content of white mustard biomass}

The $\mathrm{N}$ and $\mathrm{P}$ contents of the aboveground biomass of white mustard were significantly modified by the application of MBM and FITOdoctor, and harvest date (Table 2). The concentrations of both macronutrients in white mustard plants increased with increasing MBM rates. In comparison with the NPK treatment, the lowest and medium MBM rates ( 0.2 and $0.4 \%$ ) caused a significant decrease in $\mathrm{N}$ concentrations in white mustard biomass, whereas 
the highest MBM rate $(0.8 \%)$ significantly increased its $\mathrm{N}$ levels. Different results were obtained for the $\mathrm{P}$ content of white mustard. The effects exerted by the highest and medium MBM rates were comparable with those noted in the NPK treatment, and the lowest MBM rate significantly (by approx. 16\%) decreased P concentrations in white mustard biomass. Positive interactions were noted between the microorganisms and the medium MBM rate for $\mathrm{N}$ content, and between the microorganisms and the lowest MBM rate for $\mathrm{P}$ content. White mustard biomass harvested in the above treatments had $19 \%$ higher $\mathrm{N}$ content and $13 \%$ higher $\mathrm{P}$ content, compared with the treatments without B. subtilis. In a study by Naher et al. (2016), Bacillus sp. contributed to an increase in the concentrations of $\mathrm{N}$ and $\mathrm{P}$ in rice. Previous research has shown that bacteria mobilize poorly available forms of $P$ in soil and make them readily available to plants (Mena-Violante and Olalde-Portugal 2007). The application of Bacillus sp. with fertilizers has been found to stimulate root growth, and improve the productivity and health status of plants (Turan et al. 2007, Wang et al. 2011, García-López et al. 2015).

Second-harvest white mustard biomass had a significantly lower content of $\mathrm{N}$ and $\mathrm{P}$ than first-harvest biomass, by 37 and 9\%, respectively (Table 2). A significant (two- to three-fold) decrease in N content was observed mostly in the treatments with the lowest and medium MBM rates $(0.2$ and $0.4 \%)$. In the treatments with mineral fertilization and with the highest MBM rate, the N content of white mustard decreased 1.2 to 1.5 -fold. First- and second-harvest white mustard biomass contained more $\mathrm{N}$ in the treatment with the highest MBM rate (by 33 and $15 \%$, respectively) than in the NPK treatments. The highest decrease in P content was noted in second-harvest white mustard biomass in the treatments without mineral fertilization (approx. 21\%) and with the lowest MBM rate (approx. 15\%).

\section{Nitrogen and phosphorus uptake by white mustard}

Nutrient uptake by crop plants is one of the most important criteria for fertilizer evaluation.Increasing rates of $\operatorname{MBM}(0.2,0.4$ and $0.8 \%)$ and successive plantings significantly modified $\mathrm{N}$ and $\mathrm{P}$ uptake by white mustard (Table 3).

Table 3. Nitrogen and phosphorus uptake (g pot $\left.{ }^{-1} \mathrm{DM}\right)$ by white mustard

\begin{tabular}{|c|c|c|c|c|c|c|}
\hline \multirow[t]{2}{*}{ Treatment } & \multicolumn{3}{|c|}{$\mathrm{N}$} & \multicolumn{3}{|c|}{$\mathrm{P}$} \\
\hline & 1 & II & mean for rate & I & II & mean for rate \\
\hline 0 (no fertilizer) & 0.172 & 0.068 & $0.120^{\mathrm{a}}$ & 0.025 & 0.007 & $0.016^{a}$ \\
\hline $0+B s$ & 0.208 & 0.085 & $0.147^{a}$ & 0.032 & 0.009 & $0.020^{\mathrm{a}}$ \\
\hline NPK & 1.112 & 0.741 & $0.927^{c d}$ & 0.060 & 0.044 & $0.052^{c}$ \\
\hline $\mathrm{NPK}+\mathrm{Bs}$ & 1.039 & 1.048 & $1.044^{\mathrm{d}}$ & 0.057 & 0.067 & $0.062^{d}$ \\
\hline $0.2 \% \mathrm{MBM}$ & 0.669 & 0.185 & $0.427^{b}$ & 0.047 & 0.021 & $0.034^{b}$ \\
\hline $0.2 \% \mathrm{MBM}+\mathrm{Bs}$ & 0.734 & 0.226 & $0.480^{\mathrm{b}}$ & 0.048 & 0.029 & $0.039^{b}$ \\
\hline $0.4 \% \mathrm{MBM}$ & 1.199 & 0.418 & $0.809^{c}$ & 0.057 & 0.045 & $0.051^{c}$ \\
\hline $0.4 \% \mathrm{MBM}+\mathrm{Bs}$ & 1.440 & 0.437 & $0.938^{\mathrm{cd}}$ & 0.055 & 0.044 & $0.049^{c}$ \\
\hline $0.8 \% \mathrm{MBM}$ & 1.683 & 1.121 & $1.402^{\mathrm{e}}$ & 0.067 & 0.064 & $0.065^{d}$ \\
\hline $0.8 \% \mathrm{MBM}+\mathrm{Bs}$ & 1.904 & 1.167 & $1.536^{\mathrm{e}}$ & 0.074 & 0.072 & $0.073^{e}$ \\
\hline Mean for harvest & $1.016^{b}$ & $0.550^{\mathrm{a}}$ & - & $0.052^{b}$ & $0.040^{\mathrm{a}}$ & - \\
\hline$d \times h$ & & & & & & \\
\hline
\end{tabular}

0+Bs = Bacillus subtilis without fertilizers; NPK = mineral fertilization; MBM = meat and bone meal used at increasing rates, alone or in combination with Bacillus subtilis; I and II = first and second harvest of white mustard; $(\mathrm{d} \times \mathrm{h})=$ interaction between rate and harvest; $\mathrm{s}=$ significant difference at $p<0.01$.Values within a column (mean for rate) marked with the same letter are not significantly different at $p<0.01$

Both $\mathrm{N}$ and $\mathrm{P}$ uptake increased with increasing MBM rates which supplied 1.5, 3.0 and $6.0 \mathrm{~g} \mathrm{~N}$ pot $^{-1}$ and 1.0, 2.0 and 4.0 $\mathrm{P} \mathrm{pot}^{-1}$. In comparison with the control treatment $\left(3.0 \mathrm{~g} \mathrm{~N} \mathrm{pot}^{-1}\right)$, the highest MBM rate contributed to significantly higher $\mathrm{N}$ uptake (1.47 $\mathrm{g} \mathrm{pot}^{-1}$ on average), and the lowest MBM rate contributed to significantly lower $\mathrm{N}$ uptake ( $0.45 \mathrm{~g} \mathrm{pot}^{-1}$ on average). White mustard grown in the treatment with the medium MBM rate accumulated similar amounts of $\mathrm{N}$ to plants as those grown in the NPK treatment due to identical $\mathrm{N}$ concentration per pot in both treatments (3.0 g). Bacillus subtilis had no influence on $\mathrm{N}$ uptake by mustard. Phosphorus uptake by plants was affected by MBM rate and $B$. subtilis in two treatments, NPK and $0.8 \% \mathrm{MBM}$. The highest P uptake was noted in the treatment with the highest MBM rate applied with $B$. subtilis. Nitrogen and $\mathrm{P}$ uptake by white mustard depended on crop yield and, to a lesser extent, on the $\mathrm{N}$ and $\mathrm{P}$ content of biomass (Table 2). Similar results were obtained in previous studies with other crop species (Nogalska and Zalewska 2013, Nogalska 2016, Nogalska et al. 2017). 


\section{Soil pH}

The soil used in the experiment was acidic $(\mathrm{pH}$ in $1 \mathrm{~mol} \mathrm{KCl}=5.33)$. White mustard is sensitive to acidification, and it produces the highest yield on neutral soils. Therefore, Ca-rich MBM was used. Soil samples collected from the NPK treatments after the second harvest of white mustard were still acidic (Table 4).

Table 4. Content $\left(\mathrm{mg} \mathrm{kg}^{-1}\right)$ of mineral nitrogen forms and plant-available phosphorus, and $\mathrm{pH}_{\mathrm{KCl}}$ of soil after the second white mustard harvest

\begin{tabular}{lcccc}
\hline Treatment & $\mathrm{NH}_{4}^{+}{ }^{-\mathrm{N}}$ & $\mathrm{NO}_{3^{-}}-\mathrm{N}^{\mathrm{a}}$ & $\mathrm{P}$ & $\mathrm{pH}_{\mathrm{KCl}}$ \\
\hline 0 (no fertilizer) & $1.49^{\mathrm{a}}$ & $0.88^{\mathrm{a}}$ & $60.84^{\mathrm{a}}$ & $5.70^{\mathrm{bc}}$ \\
$0+\mathrm{Bs}$ & $2.39^{\mathrm{ab}}$ & $1.55^{\mathrm{b}}$ & $62.14^{\mathrm{a}}$ & $5.75^{\mathrm{bc}}$ \\
$\mathrm{NPK}$ & $2.66^{\mathrm{b}}$ & $1.79^{\mathrm{b}}$ & $76.67^{\mathrm{cd}}$ & $5.25^{\mathrm{ad}}$ \\
$\mathrm{NPK+Bs}$ & $2.65^{\mathrm{b}}$ & $2.34^{\mathrm{c}}$ & $67.56^{\mathrm{b}}$ & $5.16^{\mathrm{a}}$ \\
$0.2 \% \mathrm{MBM}$ & $2.41^{\mathrm{ab}}$ & $1.09^{\mathrm{a}}$ & $73.14^{\mathrm{c}}$ & $6.01^{\mathrm{c}}$ \\
$0.2 \% \mathrm{MBM}+\mathrm{Bs}$ & $1.72^{\mathrm{ab}}$ & $0.73^{\mathrm{a}}$ & $68.20^{\mathrm{b}}$ & $5.79^{\mathrm{bc}}$ \\
$0.4 \% \mathrm{MBM}$ & $2.41^{\mathrm{ab}}$ & $0.78^{\mathrm{a}}$ & $77.20^{\mathrm{d}}$ & $5.91^{\mathrm{bc}}$ \\
$0.4 \% \mathrm{MBM}+\mathrm{Bs}$ & $2.54^{\mathrm{ab}}$ & $0.77^{\mathrm{a}}$ & $69.31^{\mathrm{b}}$ & $5.80^{\mathrm{bc}}$ \\
$0.8 \% \mathrm{MBM}$ & $6.98^{\mathrm{c}}$ & $4.82^{\mathrm{d}}$ & $83.58^{\mathrm{e}}$ & $5.59^{\mathrm{bd}}$ \\
$0.8 \% \mathrm{MBM}+\mathrm{Bs}$ & $7.04^{\mathrm{c}}$ & $5.54^{\mathrm{e}}$ & $85.65^{\mathrm{e}}$ & $5.61^{\mathrm{bd}}$ \\
\hline
\end{tabular}

0+Bs = Bacillus subtilis without fertilizers; NPK = mineral fertilization; MBM = meat and bone meal applied in increasing rates alone or in combination with Bacillus subtilis. Values within a column (mean for rate) marked with the same letter are not significantly different at $p<0.01$.

A considerable increase in $\mathrm{pH}$ values was noted in MBM treatments with and without $B$. subtilis, and soil was classified as slightly acidic. An increase in the $\mathrm{pH}$ of soil fertilized with MBM was also reported by Valenzuela et al. (2000) and Deydier et al. (2003). In contrast, intensive fertilization with MBM can lower the soil pH (Nogalska et al. 2017). In the current study, the $\mathrm{pH}$ of soil decreased steadily in response to increasing MBM rates which supplied increasing amounts of Ca: 2.06, 4.12 and $8.24 \mathrm{~g} \mathrm{pot}^{-1}$. However, the observed decrease was non-significant relative to the NPK treatment. It should be noted that in MBM, Ca has the form of sparingly soluble tricalcium phosphate $\mathrm{Ca}_{3}\left(\mathrm{PO}_{4}\right)_{2}$ as well as $\mathrm{CaCO}_{3}$. In addition, $\mathrm{MBM}$ was acidic $\left(\mathrm{pH}\right.$ in $\left.\mathrm{H}_{2} \mathrm{O}=5.80\right)$.

\section{Mineral nitrogen}

In the current pot experiment, only the highest MBM rate significantly (over 2.6-fold) increased the concentrations of $\mathrm{NH}_{4}^{+}-\mathrm{N}$ and $\mathrm{NO}_{3}^{-}-\mathrm{N}$ in soil, in comparison with the NPK treatment (Table 4). The increase was observed in soil fertilized with a two-fold higher rate of $\mathrm{N}\left(6.0 \mathrm{~g} \mathrm{~N} \mathrm{pot}^{-1}\right)$ supplied by MBM, compared with soil fertilized with urea (control treatment). Despite the fact that the highest white mustard yields were achieved in the above treatments, Nmin was not efficiently utilized by white mustard plants. This suggests that the amount of $\mathrm{N}$ supplied by the highest MBM rate exceeded the $\mathrm{N}$ requirements of the tested crop species. The application of MBM at the lowest and medium rates significantly decreased $\mathrm{NO}_{3}^{-}-\mathrm{N}$ concentrations in soil, whereas $\mathrm{NH}_{4}^{+}-\mathrm{N}_{\text {concentra- }}$ tions were comparable with those determined in the control treatment. Similarly to urea, MBM contributed to a higher content of $\mathrm{NH}_{4}{ }^{+}-\mathrm{N}$ than $\mathrm{NO}_{3}-\mathrm{N}$ in soil. Therefore, it can be assumed that MBM applied at optimal rates does not contribute to $\mathrm{N}$ leaching from soil to groundwater. According to Jeng and Vagstadt (2009), the amount of $\mathrm{N}$ leached from MBM-amended soil is approximately three-fold lower, compared with mineral fertilization. In $\mathrm{MBM}, \mathrm{N}$ is present in the form of organic compounds, and it is gradually released into the soil through mineralization, thus becoming available to plants (Jeng et al. 2004, Nogalska 2013). During the mineralization of organic substances from MBM, some nutrients are released immediately whereas others (in particular N) are temporarily immobilized by soil microbes, which partially prevents $\mathrm{N}$ losses. MBM decomposition could affect the soil environment, nutrient availability to plants and $\mathrm{C}: \mathrm{N}: \mathrm{S}$ ratios in soil. The availability of $\mathrm{N}$ released during microbial decomposition of soil organic matter is determined by the $\mathrm{C}: \mathrm{N}$ ratio. If this ratio is wide (above 20), immobilization predominates (Islam and Dick 1998). In the current study, the application of B. subtilis to the soil led to a significant increase in $\mathrm{NO}_{3}^{-}-\mathrm{N}$ concentrations in three treatments: without fertilization, NPK and $0.8 \%$ MBM. Our findings are difficult to interpret. White mustard is a sulfur demanding plant, therefore sulfur deficiency (S was not applied in the experiment) could lead to reduced $\mathrm{N}$ uptake by plants. 


\section{Available phosphorus}

After two growing seasons, the available $\mathrm{P}$ content of soil increased from the initial value of $64.0 \mathrm{mg} \mathrm{kg}^{-1}$ to a high value of $76.7 \mathrm{mg} \mathrm{kg}^{-1}$ (approx. 20\% increase) in response to mineral fertilization (Table 4). The lowest MBM rate $(0.2 \%)$ supplied $1.0 \mathrm{~g} \mathrm{P}$ pot $^{-1}$, and the amount of $\mathrm{P}$ was comparable with that in the control treatment. In comparison with the NPK treatment, MBM applied at the highest rate (which supplied $4.0 \mathrm{~g} \mathrm{P}$ pot $^{-1}$ ) contributed to a significant $9 \%$ increase in the available $\mathrm{P}$ content of soil, and soil was abundant in $\mathrm{P}$, similarly to the control treatment. The $\mathrm{pH}$ of soil tended to decrease with increasing MBM rates, which led to increased accumulation of available $\mathrm{P}$ in soil. A similar relationship was noted in a previous study (Nogalska and Zalewska 2013, Nogalska et al. 2017). A beneficial influence of MBM on the abundance of plant-available $P$ in soil was also reported by Ylivainio et al. (2008) and Brod et al. (2012). In the current study, soil was significantly less abundant in available $P$ in three treatments with $B$. subtilis: NPK, 0.2 and $0.4 \%$ MBM. The available P content of soil decreased by almost $11 \%$ compared with the treatments without the microbial preparation. Different results were reported by Othman and Panhmar (2014) who observed an increase in available P concentrations in soil after the application of B. subtilis. Bacteria of the genus Bacillus belong to the most important P solubilizers (Sharma et al. 2013). They can convert insoluble $\mathrm{P}$ to soluble forms through soil acidification, enzymatic dissolution of phosphates and assimilation of ammonium ions. In our study, B. subtilis did not contribute to available $P$ release from MBM, most probably due to $\mathrm{P}$ immobilization by soil organic matter. The present results are inconclusive, contradictory and difficult to interpret, which necessitates further research.

\section{Conclusions}

This study indicates that MBM is a valuable NP fertilizer for mustard. The medium rate of MBM (4 g per 1 kg soil) was found to be optimal. The $\mathrm{N}$ and $\mathrm{P}$ content of the aboveground biomass of white mustard (Sinapis alba $\mathrm{L}$.) was significantly modified by the application of MBM and B. subtilis, and harvest date. A single pre-sowing application of the microbial preparation to the soil improved white mustard yields only during the second growing season. The $\mathrm{N}$ and $\mathrm{P}$ content of white mustard biomass was determined by their abundance in soil. Nitrogen uptake by plants and $\mathrm{N}$ concentration in biomass were highest in the treatments with the highest mineral $\mathrm{N}$ content of soil. Similar relationships were observed for $\mathrm{P}$ whose uptake by plants was also affected by $B$. subtilis in two treatments (NPK and $0.8 \% \mathrm{MBM}$ ). Nitrogen and $\mathrm{P}$ are biogenic elements which can pose an environmental threat when supplied in large quantities. Therefore, MBM rates should be adjusted to the nutrient requirements of crop species.

\section{Acknowledgements}

This research was supported by the Polish Ministry of Science and Higher Education as part of statutory activity, grant No. 20.610.002-300.

\section{References}

Al-Taweil, H.I., Bin Osman, M., Hamid, A.A. \& Yuso, W.M. 2009. Development of microbial inoculants and the impact of soil application on rice seedlings growth. American Journal of Agricultural and Biological Sciences 4: 79-82. https://doi.org/10.3844/ ajabssp.2009.79.82

Brod, E., Haraldsen, T.K. \& Breland, T.A. 2012. Fertilization effects of organic waste resources and bottom wood ash: results from a pot experiment. Agricultural and Food Science 21: 332-347. https://doi.org/10.23986/afsci.5159

Cawoy, H., Bettiol, W., Fickers, P. \& Ongena, M. 2011. Bacillus-based biological control of plant diseases. In: Stoytcheva, M. (ed.). Pesticides in the Modern World - Pesticides Use and Management. InTech. https://doi.org/10.5772/17184

Cazorla, F.M., Romero, D., Perez, G.A., Lugtenberg, B.J., Vicente, A.D. \& Bloemberg, G. 2007. Isolation and characterization of antagonistic Bacillus subtilis strains from the avocado rhizosplane displaying biocontrol activity. Journal of Applied Microbiology 103: 1950-1959. https://doi.org/10.1111/j.1365-2672.2007.03433.x

Chaves, C., Canet, R., Albiach, R., Marin, J. \& Pomares, F. 2005. Meat and bone meal: fertilizing value and rates of nitrogen mineralization. Nutrient and Carbon Cycling in Sustainable Plant-Soil Systems 1: 177-180.

Chen, L., Kivela, J., Helenius, J. \& Kangas, A. 2011. Meat bone meal as fertilizer for barley and oat. Agricultural and Food Science 20: 235-244. https://doi.org/10.2137/145960611797471552

Deydier, E., Guilet, R. \& Sharrock, P. 2003. Beneficial use of meat and bone meal combustion: "An efficient low cost material to remove lead from aqueous effluent". Journal of Hazardous Materials 101: 55-164. https://doi.org/10.1016/S0304-3894(03)00137-7

FAO 2014. World Reference Base for Soil Resources. Rome, World Soil Resources Report 106. http://www.fao.org/3/i3794en/ I3794en.pdf 
A. Nogalska et al. (2018) 27: 275-282

García-López, A.M., Avilés, M. \& Delgado, A. 2015. Plant uptake of phosphorus from sparingly available P-sources as affected by Trichoderma asperellum T34. Agricultural and Food Science 24: 249-260. https://doi.org/10.23986/afsci.49532

Harasimowicz-Hermann, G. \& Hermann, J. 2006. Function of the intercrops in protection of minerals resources and organic matter in soil. Zeszyty Problemowe Postepów Nauk Rolniczych 512: 147-155. (in Polish).

Islam, M.M. \& Dick, R.P. 1998. Effect of wheat straw carbon: Sulfur ratio on mineralization of sulfur in soils under simulated laboratory aerobic-flooding cycles. Communications in Soil Science and Plant Analysis 29: 983-995.

Jeng, A.S., Haraldsen, T.K., Vagstad, N. \& Grønlund, N. 2004. Meat and bone meal as nitrogen fertilizer to cereals in Norway. Agricultural and Food Science 13: 268-275. https://doi.org/10.2137/1239099042643080

Jeng, A.S., Haraldsen, T.K., Grønlund, A. \& Pedersen, P.A. 2006. Meat and bone meal as nitrogen and phosphorus fertilizer to cereals and ryegrass. Nutrient Cycling in Agroecosystem 76: 183-191. https://doi.org/10.1007/s10705-005-5170-y

Jeng, A.S. \& Vagstad, N. 2009. Potential nitrogen and phosphorus leaching from soils fertilized with meat and bone meal. Acta Agriculturae Scandinavica, Section B - Soil and Plant Science 59: 238-245.

Kozajda, A. \& Szadkowska-Stańczyk, I. 2012. Bacillus subtilis a legislative health problem in Poland. Medycyna Pracy 63: 91-96. (in Polish).

Mena-Violante, H.G. \& Olalde-Portugal, V. 2007. Alteration of tomato fruit quality by root inoculation with plant growth-promoting rhizobacteria (PGPR): Bacillus subtilis BEB-13bs. Scientia Horticulturae 113: 103-106. https://doi.org/10.1016/j.scienta.2007.01.031

Naher, U.A., Panhwar, Q.A., Othoman, R., Ismail, M.R. \& Berahim, Z. 2016. Biofertilizer as a supplement of chemical fertilizer for yield maximization of rice. Journal of Agriculture Food and Development 2: 16-22. https://doi.org/10.30635/2415-0142.2016.02.3

Nogalska, A. 2013. Changes in the soil nitrogen content caused by direct and residual effect of meat and bone meal. Journal of Elementology 18: 659-671.

Nogalska, A. 2016. Meat and bone meal as fertilizer for spring barley. Plant, Soil and Environment 62: 373-378. https://doi. org/10.17221/270/2016-PSE

Nogalska, A., Krzebietke, S.J., Zalewska, M. \& Nogalski, Z. 2017. The effect of meat and bone meal (MBM) on the nitrogen and phosphorus content and pH of soil. Agricultural and Food Science 26: 181-187. https://doi.org/10.23986/afsci.64207

Nogalska, A., Skwierawska, M., Nogalski, Z. \& Kaszuba, M. 2013. The effect of increasing doses of meat and bone meal (MBM) applied every second year on maize grown for grain. Chilean Journal of Agricultural Research 73: 430-434.

Nogalska, A. \& Zalewska, M. 2013. The effect of meat and bone meal (MBM) on phosphorus concentrations in soil and crop plants. Plant, Soil and Environment 59: 575-580. https://doi.org/10.17221/594/2013-PSE

Othman, R. \& Panhwar, Q.A. 2014. Phosphate-solubilizing bacteria improves nutrient uptake in aerobic rice. Phosphate solubilizing microorganisms. Switzerland: Springer International Publishing. p. 207-224. https://doi.org/10.1007/978-3-319-08216-5_9

Panak, H. 1997. Metodical Guide to Agricultural Chemistry. Wydawnictwo ART Olsztyn. (in Polish).

Patel, K.J., Singh, A.K., Nareshkumar, G. \& Archana G. 2010. Organic-acid-producing, phytate-mineralizing rhizobacteria and their effect on growth of pigeon pea (Cajanus cajan). Applied Soil Ecology 44: 252-261. https://doi.org/10.1016/j.apsoil.2010.01.002

Qiao, J., Yu, X., Liang, X., Liu, Y., Borriss, R. \& Liu Y. 2017. Addition of plant-growth-promoting Bacillus subtilis PTS-394 on tomato rhizosphere has no durable impact on composition of root microbiome. BMC Microbiology 17: 131. https://doi.org/10.1186/ s12866-017-1039-x

Rao, M.S., Kamalnath, M., Umamaheswari, R., Rajinikanth, R., Prabu, P., Priti, K., Grace, G.N., Chaya, M.K. \& Gopalakrishnan, C. 2017. Bacillus subtilis IIHR BS-2 enriched vermicompost controls root knot nematode and soft rot disease complex in carrot. Scientia Horticulturae 218: 56-62. https://doi.org/10.1016/j.scienta.2017.01.051

Sharma, S.B, Sayyed, R.Z., Trivedi, M.H. \& Gobi, T.A. 2013. Phosphate solubilizing microbes: sustainable approach for managing phosphorus deficiency in agricultural soils. Springer Plus 2: 587. https://doi.org/10.1186/2193-1801-2-587

StatSoft 2010. Statistica (data analysis Software system), version 10. www.statsoft.com

Szymczak-Nowak, J. \& Nowakowski, M. 2000. Antinematode effect and yielding of white mustard, tansy phacelia and oil radish cultivated as a main crop. Rośliny Oleiste - Oilseed Crops 21: 285-291. (in Polish).

Turan, M., Ataoğlu, N. \& Şahin, F. 2007. Effects of Bacillus FS-3 on growth of tomato (Lycopersicon esculentum L.) plants and availability of phosphorus in soil. Plant, Soil and Environment 53: 58-64. https://doi.org/10.17221/2297-PSE

Valenzuela, H.R., Goo, T., Randall, H., Hamasaki, R.H. \& Radovich, T. 2000. The effect of bone meal on the yield of jicama. Pachyrhizus Erosus in Oahu Hawaii. Proceedings of the Florida State Horticultural Society 113: 222-226.

Wang, J.B., Chen, Z.H., Chen, L.J., Zhu, A.N. \& Wu, Z.J. 2011. Surface soil phosphorus and phosphatase activities affected by tillage and crop residue input amounts. Plant, Soil and Environment 57: 251-257. https://doi.org/10.17221/437/2010-PSE

Ylivainio, K., Uusitalo, R. \& Turtola E. 2008. Meat bone meal and fox manure as P sources for ryegrass (Lolium multiflorum) grown on a limed soil. Nutrient Cycling in Agroecosystems 81: 267-278. https://doi.org/10.1007/s10705-007-9162-y

Zuo, Y. \& Zhang, F. 2011. Soil and crop management strategies to prevent iron deficiency in crops. Plant and Soil 339: 83-95. https://doi.org/10.1007/s11104-010-0566-0 